\title{
Analysis of Cases with Primary Retroperitoneal Tumors
}

\section{Primer Retroperitoneal Tümörlü Olguların Analizi}

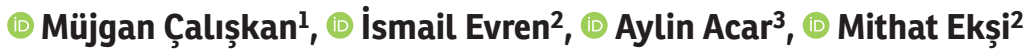 \\ ${ }^{l}$ İstanbul Medipol University, Department of General Surgery, İstanbul, Turkey \\ 2University of Health Sciences Bakırköy Dr. Sadi Konuk Training and Research Hospital, Department of Urology, İstanbul, Turkey \\ ${ }^{3}$ University of Health Sciences Ümraniye Training and Research Hospital, Department of General Surgery, İstanbul, Turkey
}

\section{ABSTRACT}

Objective: Retroperitoneal tumors are rare and most of them arise from mesodermal or neuroectodermal tissues and residues of the embryonic urogenital body. Retroperitoneal malignant tumors are seen more often than benign lesions. Due to their anatomic location and slow growth, pain and neurological symptoms do not appear until later stages. In this article, we aim to present our experience in eight cases with primary retroperitoneal tumor.

Methods: Eight patients who underwent retroperitoneal tumor excision between April 2009 and April 2016 were included in the study. Gender, age, patients' complaints, the location, type and size of the tumor, surgical techniques, and morbidity, recurrence, and mortality rates were evaluated. The mean follow-up period was 41.3 months.

Results: Four of the eight patients were females and the mean age was 48.6 years. The retroperitoneal mass was located in the abdomen ( $n=4)$ and in the pelvis ( $n=4)$. In addition to abdominal pain, some patients experienced back and leg pain, difficult urination, and constipation. Intra-operative biopsy was performed previously during a laparotomy $(\mathrm{n}=2)$. Mass excision was performed by open and laparoscopic surgery. Variable histopathological diagnoses were determined, such as schwannoma, cystic mesothelioma, angiomyolipoma, epidermoid cyst, liposarcoma, ganglioneuroma, and neurofibroma. Morbidity included intra-operative bleeding ( $n=1$ ), post-operative deep vein thrombosis $(n=2)$, and pulmonary embolism ( $n=1)$. Postoperatively there were neither recurrences nor mortality.

Conclusion: Primary retroperitoneal tumors can be located in different regions, but we did not find any tumors localized in the left lumbar region. The pathological diagnoses were heterogeneous, including seven benign lesions and one malignant lesion.

Keywords: Mesenchymal tissues; Retroperitoneum; Tumor

öz

Amaç: Retroperitoneal tümörler nadirdir ve çoğu mezodermal veya nöroektodermal kökenli olup ve embriyonik ürogenital cismin kalıntılarından kaynaklanmaktadır. Retroperitoneal malign tümörler benign lezyonlardan daha sık görülür. Anatomik yerleșimleri ve yavaș büyümeleri nedeniyle, ağrı ve nörolojik semptomlar gecikmiș așamalara kadar görülmez. Bu yazıda primer retroperitoneal tümörlü sekiz olguluk deneyimimizi sunmayı amaçladık.

Yöntemler: Nisan 2009-Nisan 2016 tarihleri arasında retroperitoneal tümör eksizyonu yapılan sekiz hasta çalıșmaya dahil edildi. Cinsiyet, yaș, hastanın șikayetleri, yeri, tümör tipi ve boyutu, cerrahi teknikler, morbidite, nüks ve mortalite oranları değerlendirildi. Ortalama izlem süresi 41,3 ay idi.

Bulgular: Sekiz hastadan dördü kadın, yaș ortalaması 48.6 idi. Retroperitoneal kitlelerin 4'ü batın $(n=4)$ ve 4'ü pelvis (n=4) yerleșimliydi. Karın ağıısına ek olarak, bazı hastalarda sırt ve bacak ağrısı, zor idrara çıkma ve kabızlık șikayetleri tespit edilmiștir. Laparotomi öncesi intraoperatif biyopsi 2 hastada uygulandı. (n=2). Kitle eksizyonu açık ve laparoskopik cerrahi ile yapıldı. Schwannoma, kistik mezotelyoma, anjiomyolipom, epidermoid kist, liposarkom, ganglionöroma ve nörofibrom gibi değişken histopatolojik tanılar belirlendi. Hastaların dördünde intraoperatif (kanama ( $n=1)$, ameliyat sonrası derin ven trombozu $(n=2)$ ve pulmoner emboli $(n=1))$ morbidite izlendi. Postoperatif dönemde rekürrens ya da mortalite izlenmedi.

Sonuç: Primer retroperitoneal tümörler farklı bölgelerde yerleșebilmekle birlikte sol lumbar bölgede herhangi bir tümör lokalizasyonu izlenmedi. Yedi benign lezyon ve bir malign lezyon da dahil olmak üzere patolojik tanı heterojen olarak belirlendi.

Anahtar Kelimeler: Mezenkimal dokular, retroperiton, tümör

Received/Geliș tarihi: 17.01.2018 | Accepted/Kabul tarihi: 18.01.2018

Address for Correspondence/Yazıșma Adresi: Mithat Ekşi, University of Health Sciences Bakırköy Dr. Sadi Konuk Training and Research Hospital, Department of Urology, İstanbul, Turkey

Phone/Telefon: +90 5062528283 E-mail/E-posta: mithat_eksi@hotmail.com ORCID-ID: orcid.org/0000-0003-1490-3756

Citation/Atıf: Çalışkan M, Evren I, Acar A, Ekși M. Analysis of Cases with Primary Retroperitoneal Tumors. Bakırköy Tıp Dergisi 2019;15:38-40. https://doi.org/10.4274/BTDMJB galenos.2018.20180117072501 


\section{INTRODUCTION}

In the context of all malignancies, retroperitoneal tumors are rarely seen and most of them arise from mesenchymal connective tissues (1). The differential diagnosis includes primary tumors of soft-tissue, lymphatic system or germ cells, primary tumors arising from a retroperitoneal organ, such as pancreas, kidneys, adrenal glands or duodenum, and distant metastasis of malignant diseases. Retroperitoneal tumors frequently arise from mesodermal or neuroectodermal tissues and residues from the embryonic urogenital body. They can arise from any part of the body since they can originate from muscle, fascia, lymphatic, adipose, vascular, or neural tissue. Retroperitoneal malignant tumors are seen more often than benign lesions. Due to their anatomic locations and slow growth patterns, pain and neurological symptoms often do not appear until the late period (2).

In this article, we aim to present our experience in eight cases with primary retroperitoneal tumors found either after clinical evaluation and radiological tests or during explorative laparotomy.

\section{MATERIALS AND METHODS}

Patients with primary retroperitoneal tumors that were referred to the Department of General Surgery between April 2009 and April 2016 were analyzed. Eight cases that underwent mass excision were included in this study. Preoperative abdominal ultrasound, computed tomography (CT), and magnetic resonance imaging (MRI) were performed in all patients to evaluate the relation of the tumor to major anatomic structures. Gender, age, patients' complaints, location and size of the tumor, surgical techniques, histopathologic diagnoses, morbidity, recurrence and mortality rates were evaluated. The mean follow-up period was 41.3 months (Range: 12- 67 months).

\section{RESULTS}

Four of eight patients included in the study were female and the mean age was 48.6 years (Range: $30-71$ years). The location of the retroperitoneal mass was abdominal in four patients and pelvic in the others. In addition to abdominal pain, the patients with a pelvic mass suffered from back and leg pain $(n=1)$, difficulty in urination $(n=1)$, and constipation $(n=1)$. In two patients, an intra-operative biopsy was performed previously during laparotomy because of surgical emergencies. All of the tumors had great vessel neighborhood, such as renal artery/vein $(n=3)$, vena cava inferior $(n=2)$, iliac artery/vein $(n=2)$ and celiac truncus $(n=1)$. Mass excision was performed laparoscopically in one patient, and via an abdominal incision in the others. Intraoperative packing was performed in one patient due to severe bleeding that occurred in the pelvic region, and after 24 hours, depacking and mass excision was performed. The mean diameter of the excised tumors was $12.3 \mathrm{~cm}$ (Range: 5-23 cm). Variable histopathological diagnoses were determined, such as schwannoma $(n=2)$, cystic mesothelioma $(n=1)$, angiomyolipoma $(n=1)$, epidermoid cyst $(n=1)$, liposarcoma $(n=1)$, ganglioneuroma $(n=1)$ and neurofibroma $(n=1)$. Deep vein thrombosis developed in two patients, and pulmonary embolism developed in one. Postoperatively there were neither recurrences nor mortality during the patients' follow-up.

\section{DISCUSSION}

Primary retroperitoneal tumors are seen rarely and $70 \%$ of them are malignant (3). Symptoms are usually not present until later in the disease. These tumors can present an asymptomatic abdominal palpable mass or symptoms related to pressure on the adjacent abdominal organs (4). Lumbosacral pain, radicular pain in lower extremity, constipation, and urinary retention accompanying nonspecific abdominal pain are commonly seen in patients with presacral localized tumors (5). In our study, five patients had no additional complaints other than having non-specific abdominal pain. In addition, presacral tumors can be detected in asymptomatic patients during a rectal examination.

Plain X-ray, CT, and/or MRI are commonly used for the diagnosis of retroperitoneal tumors. In plain X-ray, osseous widening in the sacrum, bone destruction, and/ or calcification can be observed (4). CT and MRI provide information on the size and location of the mass. However, $M R I$, which evaluates the lesion in detail, is the preferred method in regard to determining the nature of the tumor, whether it is capsulated or not, and its relation with bone and soft tissues (6). According to Ahn et al. (7) in symptomatic patients, those with a tumor size greater than $5.5 \mathrm{~cm}$ with irregular margins, those having tumors without calcification, and those patients having the presence of cystic degeneration and necrosis point to malignity in primary retroperitoneal tumors. Preoperative open biopsy or CT-guided needle biopsy can be performed, especially in 
patients for whom neoadjuvant treatment is planned (8). In the study performed by Ogose et al. (9) histopathological examination was done preoperatively in 30 cases having peripheral nerve sheath tumors, either with CT guidance or with frozen section biopsy during surgery (9).

While benign tumors can be cured by surgical excision, primary malign lesions require visceral en bloc resections (6). Treatment of benign tumors requires total removal of the tumor by laparoscopy, an open approach via laparotomy, or a posterior approach. However, the mid-line anterior abdominal and posterior retrorectal transsacral approaches are also recommended for retrorectal tumors (10). Localio et al. (11) state that maximum flexibility and the possibility for wide resection can be provided by the abdominosacral approach in the right lateral position, which provides a better chance of complete resection and allows bleeding to be controlled more easily (11). The abdominosacral approach is preferred for tumors localized above the $3^{\text {rd }}$ sacral vertebrae, and the posterior transsacral approach is preferred for tumors localized at or below the level of the $3^{\text {rd }}$ sacral vertebrae (10). The laparoscopic approach is possible even if the tumor is large and adjacent to vascular structures. In the literature, reports of laparoscopic pelvic retroperitoneal tumor excision are quite limited. It is emphasized that the laparoscopic approach is a suitable method for pelvic visualization and dissection of benign tumors in the presacral region (11).

Due to the close relation of the tumor with the sacral plexus and iliac veins, severe bleeding can occur during surgery. In addition, injuries to neighborhood organs, urinary retention after the development of neurogenic urinary bladder, anal incontinence, and loss of motor function are other complications that can be observed (5).

Intra-operative and/or postoperative complications included severe bleeding in the pelvic region $(n=1)$, pulmonary embolism $(n=1)$, and deep vein thrombosis $(n=2)$. The prognosis after total excision is generally good, and local recurrence is higher after incomplete resection. Recurrences occur in the region resected, which can be attributed to an incomplete resection. No recurrence and/ or mortality occurred in our patients.

\section{CONCLUSION}

Primary retroperitoneal tumors can be seen in different locations, but we did not see any tumors localized in left lumbar region. The pathological diagnoses were heterogeneous, including seven benign lesions and one malignant lesion.

\section{Ethics}

Ethics Committee Approval: No approval due to retrospective nature.

Informed Consent: No informed consent due to retrospective nature.

\section{Authorship Contributions}

Surgical and Medical Practices: M.Ç, A.A, Concept: M.Ç, A.A, I.E, Design: M.Ç, I.E, M.E, Data Collection or Processing: M.E, M.Ç, Analysis or Interpretation: M.E, M.Ç, Literature Search: I.E, M.C, Writing: M.Ç, A.A

Conflict of Interest: No conflict of interest was declared by the authors.

Financial Disclosure: The authors declared that this study received no financial support.

\section{REFERENCES}

1. Benissa N, Soualy K, Alouta N, Kafih M, Zerouali NO. Primary retroperitoneal tumors in adults: report of 11 cases. Ann Urol 2003;37:252-7.

2. Mullinax JE, Zager JS, Gonzalez RJ. Current diagnosis and management of retroperitoneal sarcoma. Cancer Control 2011;18:17787.

3. Pai MR, Raghuveer CV. Primary retroperitoneal tumours a 25 year study. Indian J Med Sci 1995;49:139-41.

4. Patocskai EJ, Tabatabaian M, Thomas MJ. Cellular schwannoma: A rare presacral tumour. Can J Surg 2002;45:141-4.

5. Konstantinidis K, Theodoropoulos GE, Sambalis G, Georgiou M, Vorias M, Anastassakou K, et al. Laparoscopic resection of presacral schwannomas. Surg Laparosc Endosc Percutan Tech 2005;15:302-4.

6. Pinson CW, ReMine SG, Fletcher WS, Braasch JW. Long-term results with primary retroperitoneal tumors. Arch Surg 1989;124:1168-73.

7. Ahn KS, Han HS, Yoon YS, Kim HH, Lee TS, Kang SB, et al. Laparoscopic resection of nonadrenal retroperitoneal tumors. Arch Surg 2011;146:162-7.

8. Hide IG, Baudouin CJ, Murray SA, Malcolm AJ. Giant ancient schwannoma of the pelvis. Skeletal Radiol 2000;29:538-42.

9. Ogose A, Hotta T, Morita T, Higuchi T, Umezu H, Imaizumi S, Hatano H, et al. Diagnosis of peripheral nerve sheath tumors around the pelvis. Jpn J Clin Oncol 2004;34:405-13.

10. Glasgow SC, Birnbaum EH, Lowney JK, Fleshman JW, Kodner IJ, Mutch DG, et al. Retrorectal tumors: A diagnostic and therapeutic challenge. Dis Colon Rectum 2005;48:1581-7.

11. Localio SA, Eng K, Ranson JH. Abdominosacral approach for retrorectal tumors. Ann Surg 1980;191:555-60. 